\title{
Trophic water assessment of the small retention reservoirs Blizne and Cierpisz in the Podkarpacie Region (Subcarpathian Province)
}

\author{
Małgorzata Miąsik*, Piotr Koszelnik, Lilianna Bartoszek
}

Department of Environmental and Chemistry Engineering, Faculty of Civil and Environmental Engineering, Rzeszów University of Technology, Powstańców Warszawy 12, 35-959 Rzeszów, Poland, *e-mail: msutyla@prz.edu.pl (corresponding author)

\begin{abstract}
The paper presents an analysis of the trophic status of two small retention reservoirs located in the Subcarpathian region: Blizne reservoir on the River Ladzierz and Cierpisz reservoir on the River Tuszymka. The capacity of the reservoirs is respectively $137,000 \mathrm{~m}^{3}$ and 22,000 $\mathrm{m}^{3}$ and they occupy an area of 11.46 and 2.3 hectares. The study was conducted from May to October in 2013 and in 2014. Samples of surface water were collected from two locations for each reservoir. Assessment of the trophic status of the reservoirs was based on the concentrations of phosphorus, nitrogen and chlorophyll $a$. Criteria available in the literature were used to assess the trophic status. The progress of eutrophication was also evaluated on the basis of the Trophic State Index (TSI). Analysis of the results showed that in the studied period the water of Blizne was on the border of eutrophic and hypertrophic. The fertility of the water of Cierpisz in the analysed period deteriorated from the eutrophic state to the border with hypertrophic.
\end{abstract}

Keywords: trophy, trophic indexes, small retention reservoirs.

\section{Introduction}

In Poland, small bodies of water include reservoirs with a capacity of up to $5 \mathrm{hm}^{3}$ and differ in type and size from small ponds to the backwater streams of well-developed sub-basins. These reservoirs are usually shallow, and for the greater part of the year are thermally non-stratified. They are also characterized by rapid water exchange. Small retention dam reservoirs have multiple functions. First of all, they store water and equalize flow rates, but also reduce the culmination of a flood wave. The construction of small water reservoirs also contributes to an increase in tourist and recreational values of neighbouring areas by providing places to relax in nature. Typically, these bodies receive waters from agricultural areas, resulting in the fact that many of them show signs of occurring eutrophication (Bieroński 2005).

Eutrophication of lakes is a frequent factor of anthropogenic disruption of aquatic ecosystems. The main cause of eutrophication of a water reservoir is a supply of nutrients, mainly phosphorus and nitrogen (Bajkiewicz-Grabowska 2002). The sources of nutrients in the water are primarily agriculture and domestic sewage. In effect, the increase in the concentration of nutrients causes an imbalance in the production and decomposition of organic matter in the water, therefore leading to its excessive accumulation in water and bottom sediment. In consequence, an advanced anthropogenic eutrophication process may lead to the complete degradation of the water body (Neverova-Dziopak 2013).

This paper presents an analysis of the trophic status of two small retention reservoirs, Blizne and Cierpisz, located in the Subcarpathian region. Monitoring of the trophic status of the two reservoirs is an essential element both in the management of water reservoirs and also in the management of biogenic elements in the catchment area.

\section{Study area}

The study comprised two small retention reservoirs Blizne and Cierpisz located in the Subcarpathian region. The basic morphological parameters of the examined reservoirs are shown in Table 1.

Blizne water reservoir is located in the town of Blizne, in the municipality of Jasienica Rosielna in 
Table 1. Basic morphometric parameters of studied water reservoirs (Lipińska 2011)

\begin{tabular}{lrr}
\hline \multicolumn{1}{c}{ Parameter } & Blizne Reservoir & Cierpisz Reservoir \\
\hline Area [ha] & 11.46 & 2.30 \\
\hline Volume $\left[\mathrm{m}^{3}\right]$ & 137000.0 & 22000.0 \\
\hline Maximum depth $[\mathrm{m}]$ & 3.8 & 2.0 \\
\hline Catchment area $\left[\mathrm{km}^{2}\right]$ & 18.5 & 53.4 \\
\hline
\end{tabular}

the Brzozowski district. The municipality area spreads over 5,755 hectares, of which $63 \%$ is composed of arable land and $27 \%$ of forest. The reservoir was created in 2001 on the River Ladzierz by partitioning the river valley with an earth dam of $140 \mathrm{~m}$ in length, $3.80 \mathrm{~m}$ in height and $3 \mathrm{~m}$ in width at the crown. This basin consists of two reservoirs - top and bottom. The water surface area of the bottom reservoir is 8.66 hectares, the catchment area covers $10.9 \mathrm{~km}^{2}$ and its average depth is $1.58 \mathrm{~m}$ (Czekański 2006; Lipińska 2011). The lower reservoir gives the opportunity to enjoy swimming, water sports and fishing. Its purpose is also to reduce flood tides. The upper pond with an average depth of $1.30 \mathrm{~m}$ covers an area of 2.8 hectares, and is used to retain water to supply the surrounding areas (Czekański 2006).

The other reservoir is located in the town of Cierpisz in Sedziszow Malopolski municipality in the Ropczysko-Sedziszowski district on the River Tuszymka, enclosing a small agricultural catchment area of $53.4 \mathrm{~km}^{2}$ (Madeyski 2008; Lipińska 2011). Within that catchment area the degree of afforestation amounts to $43 \%$, arable land represents $35 \%$, and finally meadows and grassland constitute 24\% (Madeyski 2008). The Cierpisz water reservoir was built in 1953 , by intersecting the Tuszymki river valley with a $2 \mathrm{~m}$ high concrete weir. The reservoir area is 2.3 hectares, and has the water capacity of $22,000 \mathrm{~m}^{3}$ (Lipińska 2011). In 1990 the reservoir was dredged by extracting $15,000 \mathrm{~m}^{3}$ of silt, which restored it to its original capacity (Madeyski 2008). This reservoir stores water and serves recreational purposes (Lipińska 2011).

\section{Methods}

Surface water samples were collected in May, July, August and October in 2013 and in May, July, September and October in 2014 from two locations for each reservoir. The research locations were situated near the dam (location 1) and near the tributary (location 2) (Figs. 1 and 2).
Using a multiparameter Hach Lange HQ40D meter, in situ, all samples were measured for temperature. A Shimadzu TOC/TC/IC analyser with an adapter for total nitrogen (TN) calculation was used in laboratory assays. Spectrophotometry was used (reaction with ammonium molybdate), to determine the total amount of phosphorus content (TP) (after prior mineralization in the presence of $\mathrm{H}_{2} \mathrm{SO}_{4}$ and peroxodisulphate) (in accordance with PN-EN ISO 6878:2006). Chlorophyll $a$ was also determined with the help of a spectrophotometer (in accordance with PN-ISO 10260:2002). In all performed analyses an Aquamate Thermo Scientific spectrophotometer was used.

The trophic status evaluation was based on the annual average content of nitrogen, phosphorus and chlorophyll $a$ (maximum for chlorophyll $a$ ) by using the trophic status classification by the Organization for Economic Cooperation and Development (Vollenweider and Kerekes 1982), Nürnberg (2001), and Forsberg and Ryding (1980) (Table 2). The progress of eutrophication was also evaluated by calculating the Trophic State Index values (TSI) by Carlson (1977) and Walker (1979) (Table 2). Calculations of the trophic indices were based on median values of measurement of the total phosphorus and chlorophyll $a$, conducted in the growing season. Due to the small depth of the researched sites, the index based on the measurement of water transparency was omitted. The Secchi disc measurement is often overlooked when assessing the trophic level of shallow water bodies, as the reduction in the transparency of the water is often not a result of the development of algae.

\section{Results and Discussion}

The results of the trophic state assessment of waters of Blizne and Cierpisz conducted pursuant to the adopted criteria (as shown in Table 2) are illustrated in Table 3.

Analysis of the trophy evaluation results of the water in Blizne in 2013 demonstrates that on the basis of all the criteria of concentration (Vollenweider and Kerekes 1982; Nürnberg 2001; Forsberg and Ryding 1980), the average concentration of total phosphorus in the water (Table 4) for the second sampling point, i.e. in the tributary area, remained within the eutrophic range, while for the sampling point situated at the dam and the average for the whole water body reached hypertrophic values. Taking into account the average concentration of chlorophyll $a$ in the water (Table 4) 


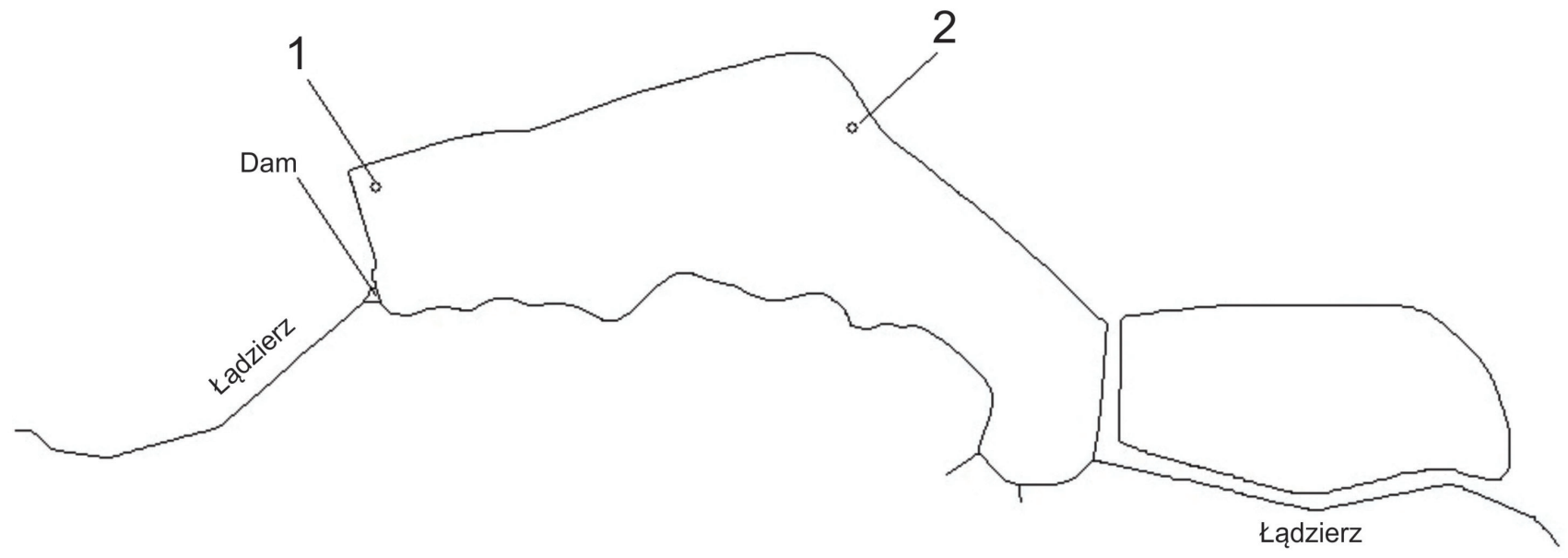

$100 \mathrm{~m}$

Fig.1. Location of the sampling stations (St) in the Blizne Reservoir

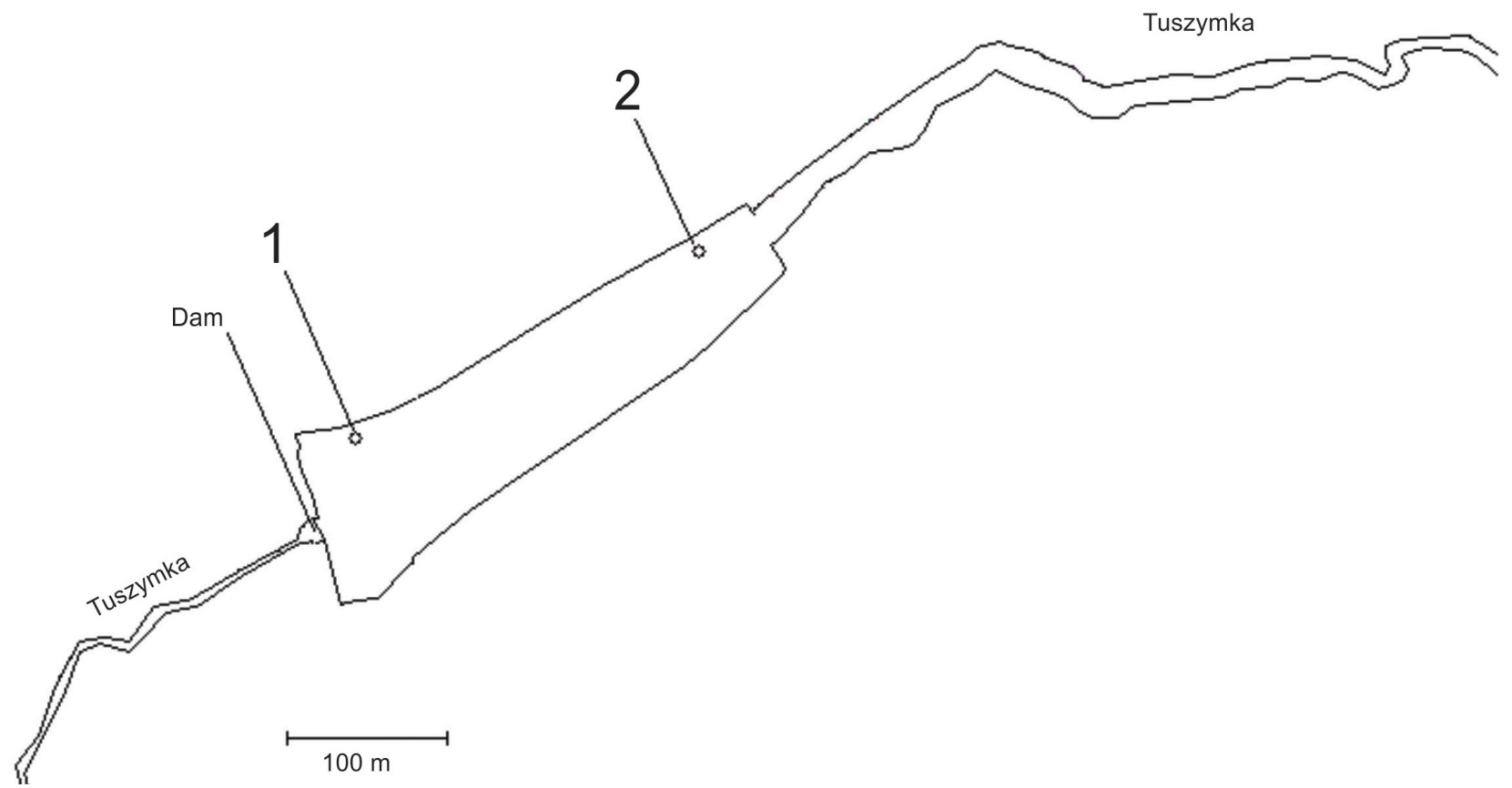

Fig.2. Location of the sampling stations (St) in the Cierpisz Reservoir

only according to the classification system of Forsberg and Ryding (1980) the water body can be classified as eutrophic; according to the other two criteria (Vollenweider and Kerekes 1982; Nürnberg 2001) it should be classified as hypertrophic. The maximum concentration of chlorophyll $a$ in the water (Table 4) at the dam showed the state of eutrophy, while that in the estuary area, as well as the average of the entire body of water reached hypertrophic values. By analysing the trophy evaluation indices, which in their general criteria include the concentration of total nitrogen in the water, the body can be classified as eutrophic, even though the average total nitrogen concentrations in the water at the dam show the mesotrophic state. The calculated values of Carlson's trophic state index for phosphorus, as well as for chlorophyll (Table 3), classify the water of Blizne as eutrophic. The analysis of calculated values of Walker's index (Table 3) give a different result. Only the water at the second sampling point appears to be eutrophic, while the water at the sampling point situated at the dam and the average of the whole water body were qualified as hypertrophic. Taking into ac- 
Table 2. Selected criteria for assessing the trophic state of lakes (Carlson 1997; Forsberg 1980; Nürnberg 2001; Vollenweider and Kerekes 1982; Walker 1979)

\begin{tabular}{|c|c|c|c|c|}
\hline \multirow{3}{*}{ Trophic state } & \multirow{3}{*}{$\begin{array}{c}\text { Total phosphorus } \\
{\left[\mu \mathrm{g} \mathrm{dm}^{-3}\right]}\end{array}$} & \multicolumn{2}{|c|}{ Chlorophyll a } & \multirow{2}{*}{ Total nitrogen } \\
\hline & & Mean & Maximum & \\
\hline & & \multicolumn{2}{|c|}{$\left[\mu \mathrm{g} \mathrm{dm}^{-3}\right]$} & {$\left[\mu \mathrm{g} \mathrm{dm}^{-3}\right]$} \\
\hline \multicolumn{5}{|c|}{ By OECD (Vollenweider and Kerekes 1982) } \\
\hline ultra-oligotrophic & $\leq 4$ & $\leq 1$ & $\leq 2.5$ & - \\
\hline oligotrophic & $\leq 10$ & $\leq 2.5$ & $\leq 8$ & - \\
\hline mesotrophic & $\leq 35$ & $\leq 8$ & $\leq 25$ & - \\
\hline eutrophic & $\leq 100$ & $\leq 25$ & $\leq 75$ & - \\
\hline hypertrophic & $>100$ & $>25$ & $>75$ & - \\
\hline \multicolumn{5}{|l|}{ By Nürnberg } \\
\hline oligotrophic & $\leq 10$ & $\leq 3.5$ & - & $\leq 350$ \\
\hline mesotrophic & $\leq 30$ & $\leq 9$ & - & $\leq 650$ \\
\hline eutrophic & $\leq 100$ & $\leq 25$ & - & $\leq 1200$ \\
\hline hypertrophic & $>100$ & $>25$ & - & $>1200$ \\
\hline \multicolumn{5}{|l|}{ By Forsberg and Ryding } \\
\hline oligotrophic & $\leq 15$ & $\leq 3$ & - & $\leq 400$ \\
\hline mesotrophic & $\leq 25$ & $\leq 7$ & - & $\leq 600$ \\
\hline eutrophic & $\leq 100$ & $\leq 40$ & - & $\leq 1500$ \\
\hline hypertrophic & $>100$ & $>40$ & - & $>1500$ \\
\hline \multicolumn{5}{|c|}{ trophic indexes } \\
\hline By Carlson & $\mathrm{TSI}($ Chla $)=9$ & +30.6 & $\mathrm{TSI}(\mathrm{TP})=$ & P) +4.15 \\
\hline oligotrophic & \multicolumn{4}{|c|}{ isl(Cnia)= 9.8T In (cnia) + 30.6 } \\
\hline mesotrophic & \multicolumn{4}{|c|}{$40-50$} \\
\hline eutrophic & \multicolumn{4}{|c|}{$50-70$} \\
\hline hypertrophic & \multicolumn{4}{|c|}{$>70$} \\
\hline By Walker & \multicolumn{2}{|c|}{$\mathrm{TSI}($ Chla $)=33.2 \log ($ Chla $)+20$} & \multicolumn{2}{|c|}{$\mathrm{TSI}(\mathrm{TP})=46 \log (\mathrm{TP})-15.6$} \\
\hline oligotrophic & \multicolumn{4}{|c|}{$<30$} \\
\hline mesotrophic & \multicolumn{4}{|c|}{$30-45$} \\
\hline eutrophic & \multicolumn{4}{|c|}{$45-65$} \\
\hline hypertrophic & \multicolumn{4}{|c|}{$>65$} \\
\hline
\end{tabular}

Table 3. Trophic status of waters in studied reservoirs ( $\mathrm{M}$ - mesotrophy, $\mathrm{E}$ - eutrophy, $\mathrm{H}$ - hypertrophy)

\begin{tabular}{|c|c|c|c|c|c|c|c|c|c|c|c|c|c|}
\hline \multirow{2}{*}{\multicolumn{2}{|c|}{$\begin{array}{l}\text { Reservoir } \\
\text { Location }\end{array}$}} & \multicolumn{3}{|c|}{ Blizne 2013} & \multicolumn{3}{|c|}{ Blizne 2014} & \multicolumn{3}{|c|}{ Cierpisz 2013} & \multicolumn{3}{|c|}{ Cierpisz 2014} \\
\hline & & 1 & 2 & Mean & 1 & 2 & Mean & 1 & 2 & Mean & 1 & 2 & Mean \\
\hline \multirow{3}{*}{ By OECD } & TP & $\mathrm{H}$ & $E$ & $\mathrm{H}$ & $E$ & $E$ & $\mathrm{E}$ & $E$ & $E$ & $E$ & $\mathrm{H}$ & $\mathrm{H}$ & $\mathrm{H}$ \\
\hline & Chla Mean & $\mathrm{H}$ & $\mathrm{H}$ & $\mathrm{H}$ & $E$ & $\mathrm{H}$ & $\mathrm{H}$ & $E$ & $E$ & $E$ & $E$ & $E$ & $E$ \\
\hline & Chla Max. & $E$ & $\mathrm{H}$ & $\mathrm{H}$ & $\mathrm{E}$ & $\mathrm{H}$ & $\mathrm{H}$ & $E$ & $E$ & $E$ & $E$ & $E$ & $E$ \\
\hline \multirow{3}{*}{ By Nürnberg } & TP & $\mathrm{H}$ & $E$ & $\mathrm{H}$ & $\mathrm{E}$ & $E$ & $E$ & $E$ & $E$ & $E$ & $\mathrm{H}$ & $\mathrm{H}$ & $\mathrm{H}$ \\
\hline & $\mathrm{TN}$ & $\mathrm{M}$ & $E$ & E & $\mathrm{M}$ & $E$ & $E$ & $E$ & $E$ & $E$ & $E$ & $\mathrm{H}$ & $\mathrm{H}$ \\
\hline & Chla Mean & $\mathrm{H}$ & $\mathrm{H}$ & $\mathrm{H}$ & $\mathrm{E}$ & $\mathrm{H}$ & $\mathrm{H}$ & $\mathrm{E}$ & $E$ & $E$ & $E$ & $E$ & $E$ \\
\hline \multirow{3}{*}{$\begin{array}{l}\text { By Forsberg and } \\
\text { Ryding }\end{array}$} & TP & $\mathrm{H}$ & $E$ & $\mathrm{H}$ & $\mathrm{E}$ & $E$ & $E$ & $E$ & $E$ & $E$ & $\mathrm{H}$ & $\mathrm{H}$ & $\mathrm{H}$ \\
\hline & $\mathrm{TN}$ & $\mathrm{M}$ & $E$ & $E$ & M & $E$ & $E$ & $E$ & $\mathrm{E}$ & $E$ & $\mathrm{E}$ & $\mathrm{E}$ & $E$ \\
\hline & Chla Mean & $E$ & $E$ & $E$ & $\mathrm{E}$ & $\mathrm{H}$ & $E$ & $E$ & $\mathrm{E}$ & $E$ & $\mathrm{E}$ & $\mathrm{E}$ & $E$ \\
\hline \multirow{2}{*}{ TSI Carlson } & TSI(TP) & $E$ & $E$ & $E$ & $E$ & $\mathrm{H}$ & $E$ & $E$ & $E$ & $E$ & $\mathrm{H}$ & $\mathrm{H}$ & $\mathrm{H}$ \\
\hline & TSI(Chla) & $E$ & $E$ & $E$ & $E$ & $\mathrm{H}$ & $E$ & $E$ & $E$ & E & $E$ & $E$ & $E$ \\
\hline \multirow{2}{*}{ TSI Walker } & TSI(TP) & $\mathrm{H}$ & $E$ & $\mathrm{H}$ & $\mathrm{H}$ & $\mathrm{H}$ & $\mathrm{H}$ & $\mathrm{H}$ & $\mathrm{H}$ & $\mathrm{H}$ & $\mathrm{H}$ & $\mathrm{H}$ & $\mathrm{H}$ \\
\hline & TSI(Chla) & $\mathrm{H}$ & $E$ & $\mathrm{H}$ & $E$ & $\mathrm{H}$ & $\mathrm{H}$ & $E$ & $E$ & $E$ & $\mathrm{H}$ & $\mathrm{H}$ & $\mathrm{H}$ \\
\hline \multicolumn{2}{|c|}{ Trophic state } & \multicolumn{3}{|c|}{ eutrophy/hypertrophy } & \multicolumn{3}{|c|}{ eutrophy/hypertrophy } & \multicolumn{3}{|c|}{ eutrophy } & \multicolumn{3}{|c|}{ eutrophy/hypertroph } \\
\hline
\end{tabular}


Table 4. Selected indicators of physicochemical properties of water in the Blizne reservoir (TN - total nitrogen, TP - total phosphorus, Chla - chlorophyll $a$ )

\begin{tabular}{|c|c|c|c|c|c|}
\hline \multirow{2}{*}{ Location } & \multirow{2}{*}{ Date } & Temperature & $\mathrm{TN}$ & TP & Chla \\
\hline & & ${ }^{\circ} \mathrm{C}$ & {$\left[\mathrm{mg} \mathrm{dm}^{-3}\right]$} & {$\left[\mathrm{mg} \mathrm{dm}^{-3}\right]$} & {$\left[\mu \mathrm{g} \mathrm{dm}^{-3}\right]$} \\
\hline \multirow{11}{*}{1} & 20.05 .2013 & 20.2 & 0.498 & 0.159 & 9.87 \\
\hline & 04.07 .2013 & 22.5 & 0.443 & 0.034 & 4.94 \\
\hline & 28.08 .2013 & 17.0 & 0.803 & 0.152 & 56.77 \\
\hline & 15.10 .2013 & 13.8 & 0.564 & 0.167 & 34.55 \\
\hline & Mean & 18.4 & 0.577 & 0.128 & 26.53 \\
\hline & 14.05 .2014 & 14.5 & 0.482 & 0.055 & 12.03 \\
\hline & 09.07 .2014 & 23.4 & 0.609 & 0.129 & 24.06 \\
\hline & 29.07.2014 & 23.0 & 0.504 & 0.038 & 9.25 \\
\hline & 04.09 .2014 & 18.5 & 0.575 & 0.054 & 19.44 \\
\hline & 09.10 .2014 & 15.3 & 0.532 & 0.049 & 13.88 \\
\hline & Mean & 18.1 & 0.871 & 0.096 & 34.56 \\
\hline \multirow{11}{*}{2} & 20.05 .2013 & 20.0 & 0.790 & 0.186 & 28.38 \\
\hline & 04.07 .2013 & 22.5 & 0.449 & 0.041 & 4.94 \\
\hline & 28.08 .2013 & 17.0 & 0.676 & 0.068 & 29.62 \\
\hline & 15.10 .2013 & 12.7 & 1.571 & 0.089 & 75.28 \\
\hline & Mean & 18.9 & 0.540 & 0.065 & 15.73 \\
\hline & 14.05 .2014 & 15.8 & 2.617 & 0.077 & 41.65 \\
\hline & 09.07 .2014 & 23.4 & 1.041 & 0.135 & 95.02 \\
\hline & 29.07 .2014 & 22.7 & 0.728 & 0.125 & 61.08 \\
\hline & 04.09 .2014 & 18.6 & 0.617 & 0.114 & 46.28 \\
\hline & 09.10 .2014 & 14.5 & 0.479 & 0.041 & 35.17 \\
\hline & Mean & 19.0 & 1.096 & 0.098 & 55.84 \\
\hline
\end{tabular}

Table 5. Selected indicators of physicochemical properties of Cierpisz reservoir (TN - total nitrogen, TP - total phosphorus, Chla chlorophyll a)

\begin{tabular}{|c|c|c|c|c|c|}
\hline \multirow{2}{*}{ Location } & \multirow{2}{*}{ Date } & Temperature & $\mathrm{TN}$ & TP & Chla \\
\hline & & ${ }^{\circ} \mathrm{C}$ & {$\left[\mathrm{mg} \mathrm{dm}^{-3}\right]$} & {$\left[\mathrm{mg} \mathrm{dm}^{-3}\right]$} & {$\left[\mu \mathrm{g} \mathrm{dm}^{-3}\right]$} \\
\hline \multirow{11}{*}{1} & 20.05 .2013 & 21.3 & 1.161 & 0.162 & 29.62 \\
\hline & 04.07 .2013 & 24.0 & 1.068 & 0.071 & 1.23 \\
\hline & 28.08 .2013 & 18.9 & 0.552 & 0.060 & 22.21 \\
\hline & 15.10 .2013 & 14.5 & 0.618 & 0.093 & 20.98 \\
\hline & Mean & 19.7 & 0.850 & 0.097 & 18.51 \\
\hline & 14.05 .2014 & 14.6 & 1.183 & 0.095 & 22.21 \\
\hline & 09.07 .2014 & 25.5 & 0.899 & 0.158 & 48.13 \\
\hline & 29.07 .2014 & 25.6 & 1.970 & 0.154 & 3.70 \\
\hline & 04.09 .2014 & 19.1 & 0.967 & 0.096 & 5.55 \\
\hline & 09.10 .2014 & 16.3 & 0.611 & 0.035 & 3.70 \\
\hline & Mean & 20.2 & 1.126 & 0.107 & 16.66 \\
\hline \multirow{11}{*}{2} & 20.05 .2013 & 21.7 & 1.172 & 0.129 & 47.20 \\
\hline & 04.07 .2013 & 23.9 & 0.990 & 0.124 & 1.23 \\
\hline & 28.08 .2013 & 18.3 & 0.509 & 0.050 & 17.28 \\
\hline & 15.10 .2013 & 14.3 & 0.403 & 0.027 & 5.18 \\
\hline & Mean & 19.6 & 0.768 & 0.083 & 17.72 \\
\hline & 14.05 .2014 & 14.7 & 2.040 & 0.122 & 57.38 \\
\hline & 09.07 .2014 & 25.5 & 0.740 & 0.114 & 46.90 \\
\hline & 29.07 .2014 & 24.8 & 1.972 & 0.181 & 5.55 \\
\hline & 04.09 .2014 & 18.8 & 1.065 & 0.092 & 5.55 \\
\hline & 09.10 .2014 & 15.2 & 0.610 & 0.030 & 1.85 \\
\hline & Mean & 19.8 & 1.286 & 0.108 & 23.45 \\
\hline
\end{tabular}


count all the criteria adopted for assessing the trophic level, in 2013 Blizne should be classified as being on the border of eutrophic and hypertrophic. The results of water analyses of Blizne in 2014, because of the concentration of total phosphorus in the water (Table 4) at the sampling point located at the dam, showed improvement in the trophic state. Therefore, according to the trophic state evaluation criteria for the concentration values for this index, the water is found to be eutrophic. However, it was also observed that at the point in the estuary area, the values of Walker's and Carlson's trophic indices for phosphorus and chlorophyll increased (Table 3). For the above reasons, in 2014 the trophy of the water of Blizne was classified, as in the previous year, as being on the border of eutrophic and hypertrophic.

The trophic state of the water of Cierpisz in 2013, on the basis of almost all adopted criteria, should be classified as eutrophic (Table 3). Only the value of Walker's index for phosphorus (Table 3) showed a higher value indicating hypertrophy. 2014 showed an increase in the concentration of total phosphorus in the water (Table 5) of Ciepisz, remaining on the hypertrophic level. It was also possible to observe the deterioration of the trophic state according to Nürnberg's classification due to an increase in the concentration of total nitrogen in the water. The results of Carlson's trophic index for phosphorus and Walker's for chlorophyll (Table 3) showed higher values than in the previous year, which lowered the classification of the trophic state from eutrophic to hypertrophic. With reference to the above, in 2014 the trophic state of the water of Cierpisz was classified as being on the border of eutrophic and hypertrophic.

\section{Conclusion}

Analysis of the results showed that in the studied period the water of Blizne was on the border of eutrophic and hypertrophic. The fertility of the water of Cierpisz in the analysed period deteriorated from the eutrophic state to the border with hypertrophic. The waters of the dam reservoirs that have been tested and analysed are located in rural areas. Therefore, it may be presumed that the cause of the high trophic status of the examined water bodies may be a consequence of an excessive supply of nitrogen and phosphorus compounds from the catchment area. Prevention of any further progress of eutrophication, which consequently leads to the loss of appeal in usable, natural, and recreational areas within water bodies, can be achieved by monitoring and forecasting changes in the trophic water status of both basins. With such a high supply of phosphorus from the drainage basin, studies should be carried out on sediments to determine its possible internal source. The results of such a study could be helpful in selecting proper remediation for the researched water bodies.

\section{Acknowledgments}

The research was funded by the National Science Centre in the framework of research project No. 2011/03/B/ST10/04998.

\section{References}

Bajkiewicz-Grabowska E., 2002, Obieg materii w systemach rzeczno-jeziornych (Circulation of matter in the river-lake systems), Wyd. UW, Warszawa, pp 274 (in Polish, English summary).

Bieroński J., 2005, Zbiorniki małej retencji - problemy funkcjonowania (Small retention ponds and reservoirs - the problems of functioning), Prob. Ekol. Kraj. 17: 101-110 (in Polish, English summary).

Carlson R., 1977, A trophic state index for lakes, Limnol. Oceanogr. 22(2): 361-369.

Czekański A., 2006, Program ochrony środowiska dla gminy Jasienica Rosielna na lata 2006-2013 (Environmental protection programme for the municipality Jasienica Rosielna in years 2006-2013), Urząd Gminy Jasienica Rosielna, Jasienica Rosielna, pp. 138 (in Polish). Retrieved from http://jasienica.bip.krosoft.pl/?mainid=76\&jb=391.

Forsberg C., Ryding S., 1980, Eurtophication parameters and trophic state indices in 30 Swedish waste-receiving lakes, Arch. Hydrobiol. 89: 189-207.

Madeyski M., Michalec B., Tarnawski M., 2008, Zamulanie małych zbiorników wodnych i jakość osadów dennych (Siltation of small water reservoirs and the quality of bottom sediments), Infrastruktura i ekologia terenów wiejskich, Ser. Monografie 11: pp. 76 (in Polish).

Neverova-Dziopak E., Kowalewski Z., 2013, Dynamika rozwoju procesów eutrofizacji w rzekach województwa podkarpackiego (Dynamics of eutrophication process development in the rivers of Subcarpathian Voivodeship), JCEEA 60(3): 47-58 (in Polish, English summary).

Nürnberg G., 2001, Eutrophication and trophic state, LakeLine 29(1): 29-33.

Lipińska E.J. (ed.), 2011, Powódź 2010 - przyczyny i skutki (Flood 2010 - causes and consequences), Biblioteka Monitoringu Środowiska, WIOŚ Rzeszów, pp 254 (in Polish).

Vollenweider R., Kerekes J., 1982, Eutrophication of waters. Monitoring assessment and control, Tech. Rep. Environ. Directorate, OECD, Paris, pp. 154.

Walker W., 1979, Use of hypolimnetic oxygen depletion as a trophic index for lakes, Water Resour. Res. 15(6): 1463-70. 